\section{Adaptation of Intestinal Amino Acid Transport}

Amino acids are absorbed against a concentration gradient by the mucosa of the small intestine ${ }^{1}$. In previous experiments we have demonstrated that active amino acid transport of rat small intestine is enhanced by an increase of dietary protein ${ }^{2,3}$. We wished to investigate in further experiments whether this change in intestinal transport is specific to amino acid transport. For this reason, transport of L-leucine was compared with transport of $d$-galactose, which is also absorbed against a concentration gradient ${ }^{4}$.

42 adult male Sprague Dawley rats (average body weight: $181 \mathrm{~g}$ ) were fed diets either low (13\% casein) or high $(88 \%$ casein) in protein for 2 weeks. The exact composition of the diets is described elsewhere ${ }^{5}$. Since against a concentration gradient than did intestinal sacs of rats fed the low protein diet. As to galactose transport there was no difference between both groups. These findings indicate a specific adaptation of active intestinal amino acid transport to the level of dietary protein intake ${ }^{12}$.

Zusammentassung. An evertierten Dünndarmsäcken (proximales Jejunum) erwachsener Ratten, die zwei Wochen lang eine proteinarme (13\% Kasein) oder proteinreiche $(88 \%$ Kasein) Diät erhalten hatten, wurde der aktive intestinale Transport von L-Leuzin und D-Galaktose untersucht. Proteinreiche Ernährung führte zu einer Stimulierung des L-Leuzin-Transports, während der D-

L-leucine and D-galactose transport by everted sacs of upper jejunum of rats fed either a low or a high protein diet

\begin{tabular}{|c|c|c|c|c|c|}
\hline \multirow[b]{2}{*}{ Diet } & \multicolumn{3}{|c|}{ L-leucine transport } & \multicolumn{2}{|l|}{ D-galactose transport } \\
\hline & Low protein & & High protein & Low protein & High protein \\
\hline Dry wt. of the everted sacs (mg). & $52 \pm 4^{\mathrm{u}}$ & $(\mathrm{n}=11)$ & $57 \pm 11 \quad(\mathrm{n}=11)$ & $47 \pm 3 \quad(n=10)$ & $49 \pm 6 \quad(n=10)$ \\
\hline $\begin{array}{l}\text { Final volume of the } \\
\text { serosal medium }(\mathrm{ml})^{\mathrm{b}}\end{array}$ & $1.00 \pm 0.02$ & 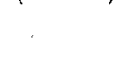 & $1.03 \pm 0.06$ & $0.99 \pm 0.04$ & $0.97 \pm 0.04$ \\
\hline$s / m$ Concentration gradients & $3.6 \pm 0.4$ & $\mathrm{p}<0.001$ & $5.3 \pm 1.3$ & $5.6 \pm 1.1$ & $5.6 \pm 0.8$ \\
\hline Serosal transfer ( $\mu \mathrm{Mol})$ & $9.3 \pm 1.9$ & $\mathrm{p}<0.01$ & $14.4 \pm 4.7$ & $16.1 \pm 3.0$ & $15.5 \pm 1.9$ \\
\hline
\end{tabular}

aS.D. ${ }^{b}$ Initial volume of the serosal medium: $1 \mathrm{ml}$. Initial volume of the mucosal medium: $20 \mathrm{ml}$.

feeding the high protein diet results in a depression of food intake ${ }^{6,7}$ the animals were pair-fed. The amount of food offered per animal and day was gradually increased from 8 to $15 \mathrm{~g}$. Thus average daily food intake during the 2 -week-period was $12.9 \mathrm{~g}$ per animal in both groups. The animals were fed twice a day. After 2 weeks on the experimental diets, average body weight of the animals was $204 \mathrm{~g}$ (low protein diet) and $207 \mathrm{~g}$ (high protein diet), respectively.

Intestinal transport of I-leucine and D-galactose was studied in vitro using everted sacs of upper jejunum according to the method of WILSON and WISEMAN ${ }^{8}$. The upper jejunum was removed under anesthesia $(0.6 \mathrm{ml}$ Equi Thesin ${ }^{9} / 100 \mathrm{~g}$ body weight). Krebs Henseleit bicarbonate puffer ( $\mathrm{pH} 7.4$ ) containing either $5 \mathrm{~m} M{ }^{14} \mathrm{C}$ labelled L-leucine ${ }^{10}$ (The Radiochemical Center, Amersham) or $5 \mathrm{~m} M \mathrm{D}$-galactose was used as incubation medium. The specific activity of the ${ }^{14} \mathrm{C}$-labelled L-leucine used was $1 \mu \mathrm{Ci} / \mathrm{mMol}$. Parameters for active transport were increases of substrate quantities in the serosal medium ( $=$ serosal transfer) during the incubation $\left(1 \mathrm{~h}, 37^{\circ} \mathrm{C}\right)$ and concentration gradients $(s / m)$ between the serosal $(s)$ and mucosal $(m)$ medium of the everted sacs at the end of the incubation. $s / m$ gradients $>1$ are indicative of active transport. ${ }^{14} \mathrm{C}$-activity was measured with a liquid scintillation spectrometer (Packard). D-galactose was determined enzymatically with galactose dehydrogenase and NAD using the test combination of Boehringer $\mathrm{GmbH}$, Mannheim.

The results are summarized in the Table. It is evident that everted intestinal sacs of rats fed the high protein diet transported significantly larger amounts of L-leucine
Galaktose-Transport dadurch unbeeinflusst blieb. Diese Befunde sprechen für eine spezifische Adaptation des intestinalen Aminosäurentransports an den Proteingehalt der Nahrung.

\section{E. SCHARRER}

Institute für Tierphysiologie und Ernährungsphysiologie der Tievärztlichen Fakultät der Universität München, Veterinärstrasse 13, D-8 München 22 (Germany), 24 September 1971.

1. G. Wiseman, in Handbook of Physiology, Section 6 (Am. Physiol. Soc., Washington, D.C. 1968), vol. 3, p. 1277.

2 E. Scharrer and H. Zucker, Z. Tierphysiol. Tierern. Futtermittelkde. 23, 169 (1967).

3 E. Scharrer and J. Brüggemann, Z. Tierphysiol. Tierern. Futtermittelkde. 27, 327 (1971).

4 R. K. Crane, Physiol. Rev. 40, 789 (1960)

5 E. Scharrer and H. ZuCker, Z. Ernährungswiss. 9, 312 (1969).

6 E. Scharrer and H. Zucker, Z. Tierphysiol. Tierern. Futtermitte]. kde 22, 141 (1967).

7 E. Scharrer, C. A. Baile and J. Mayer, Am. J. Physiol. 218, 400 (1970).

8 T. H. Wilson and G. Wiseman, J. Physiol, Lond. 123, 116 (1954).

9 Jensen Salsbery Laboratories, Richardson-Merrel Inc., Kansas City, Mo.

${ }^{10} \mathrm{~L}$-leucine is not catabolized by the small intestine ${ }^{11}$.

11 L. R. FINCH and F. J. R. HiRd, Biochim. biophys. Acta 43, 268 (1960).

12 Mit Unterstützung der Deutschen Forschungsgemeinschaft. 